\title{
Rooting for Sustainable Agriculture and Food Security Through Improved Regulatory Governance in India
}

\author{
Sunita Tripathy
}

\begin{abstract}
'Zero hunger' as a sustainable development goal requires macro-level multisectoral innovation in any regulatory setting. This is more so in the case of India, which grapples with poverty, famine, shortage in food supply and massive hike in prices of basic foodstuffs. In this chapter, I critically analyse the recent Indian efforts to overcome challenges posed by the pervasive problem of food insecurity and discuss the issues that India must overcome to position itself in a low-hunger bracket globally. In that I elaborately reflect on whether the prevailing food distribution system is being reformed to achieve aims of creating sustainable food systems through action-oriented policies. Further I contend that agroecological practices in comparison to the intellectual property-centred industrial model are the more sustainable approach in the longer run. However, the high concentration of firms in the sector seems to often create an imbalance, since capitalist tendencies outweigh the presence of any competition in the market. I argue that this imbalance has specifically led to regulatory failure in the Indian context by exemplifying the litigations concerning ag-biotech gene patents held by Monsanto. Thus, improved oversight through better understanding of the longterm goal of regulation in light of the food-health-climate nexus is the need of the hour. Preserving gene diversity, traditional farm practices and adapting to sustainable ways that aid regulatory governance in India is the plausible way to create a hunger-free future, as envisaged in UN Food and Agriculture Organisation's definition of food security.
\end{abstract}

S. Tripathy $(\bowtie)$

Jindal Global Law School, O.P Jindal Global University, Sonipat, Haryana, India e-mail: stripathy@jgu.edu.in 


\section{Keywords}

Biosafety $\cdot$ Bt cotton $\cdot$ Competition $\cdot$ Compulsory license $\cdot$ Food security $\cdot$ Gene diversity $\cdot$ Intellectual property $\cdot$ Make in India $\cdot$ Monsanto $\cdot$ Nuziveedu $\cdot$ NFSA - Right to food $\cdot$ Sustainable food systems $\cdot$ Sustainable agriculture $\cdot$ Sustainable development goals $\cdot$ Traditional knowledge $\cdot$ UNFAO $\cdot$ Zero hunger

\section{$1 \quad$ Introduction}

Food security exists when all people, at all times, have physical and economic access to sufficient, safe and nutritious food to meet their dietary needs and food preferences for an active and healthy life. - 1996 World Food Summit Plan of Action, UN FAO. ${ }^{1}$

To reduce, no later than 2015, the number of undernourished people to half the present (1996) level was a promise made at the World Food Summit after much deliberation. ${ }^{2}$ Around 12 years later, on June 19, 2009, over one-sixth of humanity

\footnotetext{
${ }^{1}$ The World Food Summit pledge of 1996 committed the World's governments to reducing, no later than 2015, the number of undernourished people to half the present (1996) level. See http://www. fao.org/docrep/w9990e/w9990e07.htm

${ }^{2}$ This number was later announced as being close to 790 million at the end of 1999, though not accounting for the number of undernourished since 1996 which was the base year as per the Summit pledge. See "Food Security: When People must live with hunger and fear starvation" (UNFAO, 1999) - The first 'State of Food security in the world' (SOFI) report, 1999 available online http://www.fao.org/3/a-x3114e.pdf. The SOFI report is jointly prepared by FAO, IFAD, UNICEF, WFP and WHO and is released annually. The UN General Assembly Resolution for adoption of Millennium Development Goals (http://www.who.int/topics/millennium_development_goals/about/en/) in September 2000 reiterated the goal with modifications in the base year as 2000 and the action of now halving "the proportion of the world's people [i.e. the entire world population]... who suffer from hunger [i.e. the number of undernourished people]." This proportion-based metric assumes an accurate calculation of the number of undernourished as a fixed number to be supported without accounting for the ever-increasing world population. Thus shifting focus to increased government action to control world population which is expected to automatically lessen the number of undernourished thereby sizing down the amount of action required to halve the number of (now reduced) hungry people. This way, any food programme that caters to the miniscule number of undernourished while the world population is uncontrollably expanding will merely register an institutional effort of window dressing for a solution to the problem of food security but not resolve the food crisis. For a descriptive critique on the approaches of international agencies such as FAO and the World Bank in remedying undernourishment, see especially, Pogge, T., "The Hunger Games" in Food Ethics, Springer, 2016, Vol 1, pp. 9-27, available online: https:// link.springer.com/article/10.1007/s41055-016-0006-9?view=classic ['Pogge, Hunger Games'] (governments kept the headline formulation of the goal - "We will halve poverty and undernourishment by 2015 " - but they [surreptiously] lowered the bar so as to make this goal more easily achievable.) The goals were further narrowed down to focus only on 'undernourishment in the developing world' and also backdated such that government action for achieving the Millennium Development Goals (MDGs) seemed to have commenced in the year 1990. Consequently, the first UN report on the progress made in regard to the MDGs depicted that world's most populous countries such as East Asia (China included) and the Pacific had succeeded in halving extreme povertyrelated concerns (such as hunger) in 1999 itself. However, subsequently the success rate diminishes
} 
was, more than ever before, reported as 'undernourished' by the United Nations' Food and Agriculture Organisation (UNFAO). ${ }^{3}$ This was also the first time in world history that the official figures had climbed above 1 billion. ${ }^{4}$ Severe shortage in food supply and massive hike in prices of basic foodstuffs were identified as the primary reason for undernourishment. ${ }^{5}$ A phase of institutional reform followed, and new metrics for calculating hunger were employed. ${ }^{6}$ The last report released by UNFAO upon the lapse of the timeline for achieving the millennium development goals in 2015, indicated that the proportion of undernourished people in the developing regions, fell by almost half since 1990 , from $23.3 \%$ in $1990-1992$ to $12.9 \%$ in 2014-2016. ${ }^{7}$ Such assertions notwithstanding, the World Food Price Index was found spiking from 201.4 in 2008 to 229.9 in 2011 and more recently to 163.5 in

considerably reflecting uneven progress. For the first UN Report, see United Nations, 'Implementation of United Nations Millennium Declaration: Report of the Secretary-General' (July 31, 2002) available online: http://www.un.org/millenniumgoals/sgreport2002. pdf?OpenElement; for the last UN Report, "Millennium Development Goals Report 2015", see http://www.un.org/millenniumgoals/2015_MDG_Report/pdf/MDG\%202015\%20rev\%20 (July\%201).pdf.

${ }^{3}$ See UNFAO, “1.02 Billion People Hungry” (June 19, 2009) available online: http://www.fao.org/ news/story/en/item/20568/icode/. See also Conway, G., One Billion Hungry: Can We Feed The World (Cornell University Press, New York, 2012) - the routes to World Food Security are technological innovation, fair and efficient markets, people and political leadership.

${ }^{4}$ These official figures may be an understatement of the real-world scenario as the earlier FAO metric for measuring 'undernourishment' overlooks nutritional deficiency in food intake (such as necessary vitamins and their absorption for healthy and balanced living), energy expenditure due to work (as opposed to sedentary lifestyle), famine or disease and merely focuses on state of dietary energy deprivation lasting over a year. Clearly discounting extended periods of short-term starvation that last under a year's duration. See for example, ['Pogge, Hunger Games'] supra at 1 for a critique on the FAO definition of undernourishment.

${ }^{5}$ See Timmer, P., 'Reflections on Food Prices Past' in Food Policy, Elsevier, February 2010, Issue 1, Vol 35, pp. 1-11 - from the beginning of 2007 to early 2008, the prices of some of the most basic international food commodities increased dramatically on international markets.

${ }^{6}$ After the Global Food Crisis (See fn.2), the old FPPI was redesigned by the Committee on World Food Security (CWFS). The now reformed CWFS convened a High Level Panel of Experts (HLPE) for Food Security and Nutrition in October 2009 and developed an expert report for new FPPI along with recommendations for monitoring undernourishment before the expiration of the timeline for realization of the Millennium Development Goals (http://www.who.int/topics/millennium_development_goals/about/en/). The new FPPI depicted 13\% reduction in undernourishment which co-related with World Bank's cumulative extreme poverty decline since 1996 reported after the WTO Ministerial Conference in Seattle in November 1999. See especially, ['Pogge, Hunger Games'] supra at 2- "[The new method] ensured, at least, that the officially reported undernourishment and extreme poverty trends were now firmly headed in the same direction."; see also ["Special Feature article on the New FPPI, 2013"] at fn 8; see also HLPE Secretariat, UNFAO, "The High Level Panel of Experts on Food Security and Nutrition: Key elements" available online: http://www.fao.org/fileadmin/user_upload/hlpe/hlpe_documents/HLPE_Key_elements_EN.pdf

${ }^{7}$ UN Report, "Millennium Development Goals Report 2015" see http://www.un.org/millenniumgoals/2015_MDG_Report/pdf/MDG\%202015\%20rev\%20(July\%201).pdf 
October $2018 .^{8}$ Food prices have only continued to remain volatile over the years, ${ }^{9}$ and India, the highest exporter of rice in the world, ${ }^{10}$ grapples with food insecurity still.

The promise made in 1996 has been rechristened as one of the sustainable development goals (SDGs) to be achieved by the year $2030 .{ }^{11}$ Newer policies and regulatory measures ought to have been designed to achieve the 'zero hunger' goal by then. It is worthwhile to consider whether this goal-shifting will help resolve the problem of hunger or at least make it manageable for countries such as India. These concerns constitute the main premise of this chapter.

Pragmatically speaking, a hunger-free future, as envisaged in the definition above, requires innovation in food regulation overall. From regulating innovation in food production techniques (farming and seed cultivation) to innovation that safeguards the produce from contamination (due to reasons of ecological imbalance or human-activity), while ensuring adequate supply and successful distribution through innovative government strategy, food security as a development goal requires macro-level multisectoral innovation in any regulatory setting. For instance, at the national level, strategies employing subsidies or what is referred to as expenditure tax credits to innovative firms, specifically tailored national intellectual property (IP) policy that benefits important sectors and activities that foster collaborative partnerships between public and private firms for effective distribution, characterize policies that are vital catalysts for achieving the goal.

In a similar vein, aiming for skill enhancement and job creation in over $25 \mathrm{sec}$ tors (including agriculture), the Indian government launched the 'Make in India'

\footnotetext{
${ }^{8}$ See UNFAO, "Food Price Index" in World Food Situation (November 01, 2018) available online: http://www.fao.org/worldfoodsituation/foodpricesindex/en/; for a discussion on the methodology for determining the FFPI and measurements that assess trends in food prices, see Ali Arslan Gurkan, "FAO's Food Price Index Revisited" Food Outlook (November 2013) available online: http://www.fao.org/fileadmin/templates/worldfood/Reports_and_docs/Special_feature_FFPI_ en.pdf ["Special Feature article on the New FPPI, 2013"]

${ }^{9}$ See ['Pogge, Hunger Games'] supra at 2. The World Food Crisis due to the exorbitant food prices had led to food riots in several developing economies including Bangladesh, Bolivia, Brazil, Burkina Faso, Cameroon, Egypt, Ethiopia, Haiti, India, Indonesia, Ivory Coast, Mauritania, Mexico, Morocco, Mozambique, Myanmar, Pakistan, Senegal, Somalia, South Africa, Sri Lanka, Tajikistan, Uzbekistan and Yemen.

${ }^{10}$ See US Department of Agriculture, "Principal Rice Exporting Countries worldwide in 2017/18 (in 1000 metric tons)" in Statista (As of February 2018, rice export of India was projected to amount to some 12.5 million metric tons) available online: https://www.statista.com/statistics/255947/top-rice-exporting-countries-worldwide-2011/; see also Cahill, C and Gulati, A., OECD/ICRIER (2018), "Agricultural Policies in India" OECD Food and Agricultural Reviews, OECD Publishing, Paris (Despite... notable achievements, challenges remain; among them, the prevalence of very large numbers of smallholders, low productivity, climate change, pressure on natural resources such as water, persistent food insecurity, and an under-developed food processing and retail sector), available online: https://read.oecd-ilibrary.org/agriculture-and-food/agriculturalpolicies-in-india_9789264302334-en\#page4 ['OECD/ICRIER 2018 Report']

${ }^{11}$ The '2030 Agenda for Sustainable Development' still encompasses food security as a major goal. See "Zero Hunger" enlisted as sustainable development goal\# 2, available online: https://www. un.org/sustainabledevelopment/hunger/
} 
initiative in the year 2014. ${ }^{12}$ As a result, national strategies integrating employment for farmers and approaches to tackle their vulnerability via climate adaptation, social protection and disaster risk reduction were called for. Since food systems account for $30 \%$ of human-caused greenhouse gas emissions, ${ }^{13}$ emphasis on shifting to the low-carbon economy as the low-cost path to long-term international competitiveness and environmental sustainability as per the Cartagena Dialogue ${ }^{14}$ now constitutes positive action points at the policy level. These efforts may well mark the beginning of a trend to address the food-health-climate nexus and remedy the problem of uninformed and ineffective policy. ${ }^{15}$ It thus, becomes imperative to take a closer look at the regulatory challenges faced by India and the solutions that it has been subscribing to as part of its mandate to realize this sustainable development goal. Prominent in such analysis emerges the tale of violations in the ag-biotechnology sector, and its deleterious effects on food security in India. In this chapter, I will critically analyse the recent Indian efforts to overcome challenges posed by the pervasive problem of food insecurity and discuss the regulatory challenges that India must overcome to position itself in a low-hunger bracket globally.

The discussion in the chapter is structured into three main parts, wherein, the first part elaborates on the aims of creating 'sustainable food systems'; second part compares agroecological practices with the IP-centred industrial model from a sustainability lens; the third part ponders on the problems emerging from the trend of relying on genetic engineering for production of food and agriculture in India; and the concluding section summarizes the views advanced by emphasizing the importance of effective regulation to address the aspirational goals of food security.

\footnotetext{
${ }^{12}$ For description of 'Make in India', see India Brand Equity Foundation,

https://www.ibef.org/economy/make-in-india. Also see Key highlight of Union Budget 20172018 includes plans to double the income of farmers in 5 years as part of the Agenda 2017-2018 "Transform, Energise and Clean India". https://www.indiabudget.gov.in/budget2017-2018/ ub2017-18/bh/bh1.pdf

${ }^{13}$ See generally, World Resources Institute in collaboration with the World Bank, UNEP, UNDP,CIRAD and INRA, "Creating a sustainable food future: Interim findings," WRI Report 2013-2014 (Washington DC: WRI) at p.73, 83-89, available online: https://wedocs.unep.org/bitstream/handle/20.500.11822/10731/CreatingSustainableFoodFuture.pdf?amp\%3BisAllowed=\&s equence $=1$

${ }^{14}$ India is one of the 40 countries that are committed to becoming (now remaining) low-carbon countries and is working towards a legally binding Agreement under the United Nations' Framework Convention on Climate Change (UNFCCC). Five regional groups (including Asian States) came together to form this group which was founded in Cartagena, Columbia in 2010 after COP12 in Copenhagen in 2009. For more details on the negotiations, see online: http://www.cicep. no/copguide/2015/10/25/cartagena-dialogue

${ }^{15}$ See generally, Tripathy, S and Rosencrantz, A., "Climate impacts food security and health" (March 25, 2018). The Statesman https://www.thestatesman.com/opinion/climate-impacts-foodsecurity-health-1502607709.html - The recent unusual smog occurrence in New Delhi and Haryana between November 2017 and February 2018 ... came to be incorrectly explained as environmental contamination caused due to vehicular pollution. Actually, the practice of burning residual crop stubble is the main reason for elevated rates of airborne particulate matter in the area...The pollutants further deteriorate the soil composition which makes farming susceptible to pests; and the pests are treated with more chemicals and pesticides which go on to contaminate the upstream food chain again - leading to the vicious cycle that engenders consumer health.
} 
Admittedly, 'right to food' may just be the starting point to regulatory implementation, thus newer approaches that compliment it are also suggested to achieve an improved food future for India.

\section{Sustainable Food Systems: An Ideal Approach}

Availability, accessibility and adequacy remain recurring concerns while developing policies to achieve 'zero hunger'. Climate change and land limitations are also emerging as critical factors that compound the problem of food insecurity at a global scale. Notably, '[i]ncreasing food insecurity is likely to intensify debates about patenting of seeds and plant variety protection, fueling calls for compulsory licensing provisions akin to those used to provide access to life-saving medicines in developing countries'. ${ }^{16}$ With a population of over 1.35 billion, India can achieve food security only through measured proactive steps.

Interestingly, India was the ninth largest exporter of agricultural products in 2017, and the sector constitutes a share of $13 \%$ of total exports of the country. ${ }^{17}$ However, incidence of poverty contributes to the persistence of food insecurity at the domestic level. Additionally low nutritional quality of food has led to increase in stunting and wasting of large sections of the population. ${ }^{18} \mathrm{~A}$ historical understanding of the regulatory framework to counter these challenges can help shed light on the reasons behind the government action, which allows for an opportunity to scrutinize them objectively.

\subsection{Food Distribution as a Policy: The Why's and How To's for India}

Food security has always featured as an important component of the agricultural policy. Regulatory reforms in the sector came about as a measure to counter the disastrous impact of the Bengal Famine of $1943 .{ }^{19}$ The Indian public distribution system

\footnotetext{
${ }^{16}$ Leidwein, A., "Food Security, climate change and IP rights" - WIPO Magazine, 2011. Also note that similar debates have started to ensue in relation to climate resilient plant and seed varieties.

${ }^{17}$ India Brand Equity Foundation Report 2018, "Agriculture in India: Information about Indian agriculture and its importance," (September 2018) available online: https://www.ibef.org/industry/ agriculture-india.aspx

${ }^{18}$ Supra ['OECD/ICRIER 2018 Report'] at fn 10

${ }^{19}$ See Swaminathan, M.S., "From Bengal Famine to Right to Food" The HINDU (February 13, 2013) available online: https://www.thehindu.com/opinion/lead/From-Bengal-Famine-to-Rightto-Food/article12342992.ece; notably post-second world war, food had become crucial for longterm peace and post-war reconstruction globally as well. In 1943, a conference on food and agriculture was convened that led to the institutional development of the UNFAO and eventually the international harmonization of food standards started in earnest through the Codex Alimentarius Commission, a subsidiary body of the FAO and the WHO. See specifically, Drahos, P and Braithwaite, J, (2000) "Ch. 16: Food" in Global Business Regulation (Cambridge University Press, England: 2000) at 400 .
} 
(PDS) was designed to address the consequent inequality. ${ }^{20}$ However, the scheme was found to aid distribution of food grains to urban areas mostly and was later revamped in 1992 to specifically include remote areas of India. The revamped PDS was further replaced by the targeted PDS (TPDS) in 1997. TPDS focused on distribution of food grains to the impoverished in every area - urban and remote - of the country. The categorization was done in terms of the household income, i.e., households below the poverty line (BPL) would constitute the beneficiaries of the scheme. Foodstuffs were made available at subsidized rates for the BPL category.

In order to support the poorest of the poor, in the year 2000, a new scheme Antyodaya Anna Yojana (AAY) introduced further subsidies for the extremely marginalized BPL households. These schemes along with the other welfare schemes (OWS) especially the wheat-based nutrition programme and midday meal provisions were consolidated as a common policy goal. Finally, the 'right to food' as a legal entitlement was incorporated within the newly enacted National Food Security Act (NFSA) in September 2013. ${ }^{21}$ The coverage under the NFSA has been delinked from poverty estimates and is based on officially reported consumption expenditure of households. ${ }^{22} \mathrm{~A}$ further change in categorization of beneficiaries distinguished between the priority households (including all BPL and some above the poverty line (APL) beneficiaries) and the AAY households under the TPDS. Each AAY household is entitled to 35 kilogramme of food grains per month, while priority category beneficiaries are entitled to 5 kilograms of grains per person per month. The issue price is fixed as rice, 3 INR; wheat, 2 INR; and coarse grains, 1 INR per kilogramme by the central government, and no price-fluctuations would be experienced for at least 3 years. ${ }^{23}$ It has been noted that the issue price has remained unchanged since $2013,{ }^{24}$ but objective reports evaluating the claims of marked improvement in food security at the household level are unavailable.

The aforementioned schemes have been operationalized through the centralized procurement undertaken by the Food Corporation of India (FCI) and the decentralized procurement facilitated by authorized agencies which hold and distribute grains in certain remote regions of the country. ${ }^{25}$ The FCI procures food grains from farmers at

\footnotetext{
${ }^{20}$ Government of India (2017), Department of Food and Public Distribution, Ministry of Consumer Affairs, Food and Public Distribution, "Targeted Public Distribution System," available online: https://dfpd.nic.in/public-distribution.htm

${ }^{21}$ Government of India (2013), Department of Food and Public Distribution, Ministry of Consumer Affairs, Food and Public Distribution, National Food Security Act, see https://dfpd.nic.in/LwB3A HIAaQB0AGUAcgB1AGEAZABkAGEAdABhAC8AUABvAHIAdABhAGwALwBNA GEAZwBhAHoAaQBuAGUALwBEAG8AYwB 1 AG0AZQBuAHQALwA=1_43_1_ NFS-Act-English.pdf ['NFSA 2013']

${ }^{22}$ The Planning Commission relied on the National Sample Survey Office (NSSO) data on consumption expenditures for the TPDS scheme under the NFSA.

${ }^{23}$ See supra ['OECD/ICRIER 2018 Report'] at fn 10.

${ }^{24}$ Ibid, ['OECD/ICRIER 2018 Report'] at fn 10.

${ }^{25}$ Government of India (2015), Press Information Bureau, Department of Food and Public Distribution, Ministry of Consumer Affairs, Food and Public Distribution, "Decentralized procurement to be encouraged to enhance the efficiency" (December 15, 2015) available online: http://pib. nic.in/newsite/PrintRelease.aspx?relid=133255; for a comparable understanding of the efficiency
} 
the minimum support price (MSP) predetermined by the Cabinet Committee on Economic Affairs based on the recommendations of the Commission for Agricultural Costs and Prices (CACP) ${ }^{26}$ These grains are stored and accounted according to operational stocks that are distributed under the TPDS and OWS and the food security stocks that are utilized to meet shortfalls and supply inadequacies. ${ }^{27}$ According to the NFSA, changes to the issue price can be made by the central government on the condition that in no event does the issue price exceed the MSP. Also, in order to counter problems of availability due to a lean season or to stabilize market prices, the central government can direct the FCI to release food stock at predetermined minimum issue price in the domestic market under the Open Market Sales Scheme (OMSS) or have State trading enterprises and private agencies export the grains.

Despite these, food security self-sufficiency at the national level remains illusionary due to implementation failure. ${ }^{28}$ It is my view that the regulatory framework would be efficient once the relation between the regulation and the risk it seeks to avoid is clearly gauged. Risk posed due to food security can be better tackled when the informational gaps that contribute to the continuity of the social problem are ascertained. An independent body of specific domain experts - a plurality of knowledgeable minds - that can be brought together and funded to study existing data sets as a multi-sectoral problem, identify areas for research, depute teams for data collection, analyse data so collected based on prevalent indices in that discipline, conduct stakeholder consultations and present findings supported by policy prescription for effective implementation and compliance. Such 'openness' in regulatory decision making, can effectuate relevant research to plug the gaps, provide objective evaluation, generate public awareness and build trust in the system through a practicable roadmap for a nourished and healthy India. In essence, failure to effectively distribute can be checked by means of an enforcement structure akin to 'responsive regulation' making agencies accountable for improving the food

of the decentralized procurement system, see also Government of India (2013), Press Information Bureau, Department of Food and Public Distribution, Ministry of Consumer Affairs, Food and Public Distribution, "Center to Encourage Decentralized Procurement" (March 05, 2013) available online: http://pib.nic.in/newsite/PrintRelease.aspx?relid=93033

${ }^{26}$ Government of India (2017), Commission for Agricultural Costs and Prices, Ministry of Agriculture and Farmers Welfare, "Determinants of MSP" available online: https://cacp.dacnet. nic.in/content.aspx?pid=62. The MSP is fixed by considering several factors such as the cost of production, the domestic and international price trends.

${ }^{27}$ Food Corporation of India (2017), see online: http://fci.gov.in/aboutUs.php. The Food Corporation of India was setup under the Food Corporation's Act 1964, in order to fulfill following objectives of the Food Policy: (i) effective price support operations for safeguarding the interests of the farmers, (ii) distribution of food grains throughout the country for public distribution system and (iii) maintaining satisfactory level of operational and buffer stocks of food grains to ensure National Food Security. Since its inception, FCI has played a significant role in India's success in transforming the crisis management-oriented food security into a stable security system.

${ }^{28}$ See The Economic Times, "National Food Security Act not implemented as it should be: Supreme Court" (July 21, 2017) available online: https://economictimes.indiatimes.com/news/politics-andnation/national-food-security-act-not-implemented-as-it-should-be-supreme-court/articleshow/59702676.cms. 
distribution effects. ${ }^{29} \mathrm{~A}$ new policy wing, the National Institution for Transforming India (NITI) or 'Niti Aayog' which came into existence in 2014, is the main body currently undertaking all policy evaluations. ${ }^{30}$ Being a government-funded think tank that was institutionalized after replacing the erstwhile Planning Commission instituted in 1950, Niti Aayog may not be considered independent. Effective policy formulation and implementation deserves intermittent and objective evaluation for the purposes of growth and consistency.

\subsection{Sustainable Agriculture for Practicable Food Security: The Law and Policy of It}

The price of key staples for world food supply will increase $70-90 \%$ by 2030 , relative to 2010 prices, before the effects of climate change. ${ }^{31}$ In order to meet the domestic demands of the consumers in 2050, agriculture in India is required to grow annually at nearly $3 \%$ to keep pace with the rising populations. ${ }^{32}$ One way to ensure such growth is to incentivize adoption of 'sustainable agriculture' as a matter of practice.

\footnotetext{
${ }^{29}$ See Braithwhite, J., "Responsive regulation and developing economies" World Development, 2005, 34: 884-98; see also Braithwhite, J., "The essence of responsive regulation" University of British Columbia L. Rev., 2011, 44: 475-520; also take note that group of actors united by common regulatory discourse and technical expertise constitute an important 'epistemic community' who can help achieve the goals of regulatory globalization cautiously. See especially, Drahos, P., "Regulatory Globalisation" in Drahos, P ed., Regulatory Theory, Foundations and Applications (Australian National University Press, 2017) at 253; for role of experts in ensuring compliance, see also Parker, C and Nielsen, V., "Compliance: 14 Questions" in Drahos, P ed., Regulatory Theory, Foundations and Applications (Australian National University Press, 2017) at 229. For a descriptive understanding of empirical work undertaken for developing regulatory frameworks, see especially, Henne, K., "Multi-sited fieldwork in regulatory studies" in Drahos, P ed., Regulatory Theory, Foundations and Applications (Australian National University Press, 2017) at 97.

${ }^{30}$ See National Institution for Transforming India (NITI Aayog) http://niti.gov.in/ - The government of India, in keeping with its reform agenda, constituted the NITI Aayog to replace the Planning Commission. This was done in order to better serve the needs and aspirations of the people of India. An important evolutionary change from the past, NITI Aayog acts as the quintessential platform of the government of India to bring States to act together in national interest and thereby fosters cooperative federalism.

${ }^{31}$ Bailey, R., Oxfam International Report on "Growing a Better Future: Food justice in a resourceconstrained world" (May 31, 2011) at 6, 12

${ }^{32}$ National Academy of Agricultural Research Management, NAARM Vision 2050, Indian Council of Agricultural Research, available online: https://naarm.org.in/publications/naarm-vision-2050/. Definitional description of sustainable agriculture at the international level includes, "the management and conservation of the natural resource base, and the orientation of technological change in such a manner as to ensure the attainment of continued satisfaction of human needs for present and future generations'. See UN FAO, "Building a common vision for sustainable food and agriculture: Principles and approaches"(2014) available online: http://www.fao.org/3/a-i3940e.pdf. Ideally, sustainable food systems would entail the following important components: (i) viable food economy for farmers and producers; (ii) accessibility and affordability for consumers; (iii) nutritious, healthy and wholesome food; (iv) sound environmental stewardship; (v) cultural heritage and customs evolving within communities; (vi) effective use of technology; and (vii) clear distinction between sustainability from organic.
} 
The 'successful management of resources for agriculture, to satisfy the changing human need while maintaining ecological balance by avoiding depletion of natural resources' is referred to as 'sustainable agriculture' in India. ${ }^{33}$ Building sustainable food systems has been undertaken as part of the National Mission for Sustainable Agriculture (NMSA), which is one of the eight missions introduced under the National Action Plan on Climate Change (NAPCC) by the government on June 30, $2008 .{ }^{34}$ It focuses on four main areas, namely, (i) dryland agriculture, (ii) risk management, (iii) access to information and (iv) use of biotechnology. ${ }^{35}$ The aim is to make appropriate adaptation and mitigation strategies for combating climate change-related effects on Indian agriculture and thereby warranting food security and enhancing ecological sustainability. Integrated farming practices and agroforestry techniques are detailed in operational guidelines and are to be monitored through progress reports periodically. While the aims of the mission are noble and can contribute towards knowledge sharing of sustainable practices, there is no express compliance requirement for it. Thus the mission may be understood as a nudge towards adopting sustainable agriculture. ${ }^{36}$ With increased stakeholder engagement at the grass-root level, it could very well transform into an effective responsive regulation qualified with appropriate mandates and deliverables in the longer run.

A conjoint reading of Articles 39, 43 and 47 which feature as Part IV of the Indian Constitution denoting the Directive Principles of State Policy recognizes the 'right to adequate food' as a legislative mandate. ${ }^{37}$ Accordingly, all citizens have the right to adequate means of livelihood, for which the State shall endeavour to provide a decent standard of life for everyone and raise levels of nutrition and improve public health as among its primary duty. Furthermore, India became State party to the International Covenant on Economic, Social and Cultural Rights (ICESCR) in 1979 by way of accession - recognizing everyone has a right to [...] be free of hunger. ${ }^{38}$ It is also

\footnotetext{
${ }^{33}$ See National Mission for Sustainable Agriculture (NMSA), available online: https://nmsa.dac. gov.in/

${ }^{34}$ See Department of Science and Technology, "Climate Change Programme" available online http://www.dst.gov.in/climate-change-programme; see also Yasmin, S and Sheikh, M.A., "Sustainable Agriculture: A Legal Perspective," International Journal of Socio-Legal Analysis and Rural Development L. Vol. 2 No. 1, 125, 126 (2016).

${ }^{35} \mathrm{Id}$ at 128

${ }^{36}$ See Thaler, R and Sunstein, C, Nudge, Improving Decisions About Health, Wealth and Happiness (Yale University Press, 2008); for a general understanding of what constitutes a nudge success, see Kosters, M and van der Heijden, J, "From mechanism to virtue: Evaluating Nudge Theory" in Evaluation 21:276-91; note that awareness of the benefits of nudges can allow freedom to alter behaviour as opposed to addressing digression through command and control. For a critique on consumer choices shaped through nudges from supermarkets, see Drahos, P and Krygier, M., "Regulations, Institutions and Networks" in Drahos, P ed., Regulatory Theory, Foundations and Applications (Australian National University Press, 2017) at 1.

${ }^{37}$ For text of Articles 39, 43 and 47 of the Indian Constitution, see online https://www.india.gov.in/ sites/upload_files/npi/files/coi_part_full.pdf at p. 21, 22 and 23, respectively.

${ }^{38}$ Article 11 of ICESCR, 1966
} 
obligated as a signatory to the Universal Declaration of Human Rights (UDHR) to take measures so that 'everyone has a right to standard of living adequate for the health and well-being [...] including food, clothing, medical care and necessary social services' ${ }^{39}$ With $48 \%$ of children under the age of 5 being stunted, $43 \%$ being underweight and 7 out of every 10 children between 6 and 59 months are reported anaemic, ${ }^{40}$ India is challenged with a crisis of malnourishment and requires strategic action. Sustainable agriculture may well be the path for India to confer food security in a practicable way by minimizing social inequality and poverty ${ }^{41}$ through sustained State action.

\subsection{Regulatory Aims, Efforts and Challenges}

Institutional credit to the agriculture sector is targeted at Rs. 11 lakh crores ( US\$ 172.93 billion) for 2018-2019 in the Union Budget. ${ }^{42}$ The total allocation for the rural, agriculture and allied sectors in 2017-2018 - Rs. 1,87,223 crores, which is

\footnotetext{
${ }^{39}$ Article 25 of UDHR, 1948

${ }^{40}$ See especially, Grebmer, K et al., "2017 Global Hunger Index - The Inequalities of hunger" International Food Policy Research Institute (IFPRI) publication at 12, available online: http:// ebrary.ifpri.org/utils/getfile/collection/p15738coll2/id/131422/filename/131628.pdf (See Table 2.1 at 13 - "At 31.4 India's 2017 GHI score is at the high end of the serious category" at 12); also see The MINT, "The fuzzy numbers on child malnutrition" (October 14, 2014) available online https:// www.livemint.com/Opinion/bgIJC0LykMr6iwAYSUfMNJ/The-fuzzy-numbers-on-childmalnutrition.html that discusses the India case study and the pervasive problem of malnutrition since 2004 to 2014; also, for press reports on alarming food insecurity and the slow improvement, with India ranking 55th out of 76 nations in the Global Hunger Index in 2014, see BusinessLine, "India moves up 8 places on Global Hunger Index" (October 29, 2014) available online: https:// www.thehindubusinessline.com/economy/India-moves-up-8-places-on-Global-Hunger-Index/ article20898587.ece; the depth of food deficit (kilocalories per person per day) estimates has been staggering over the years with almost 20 crore ( 200 million) people being undernourished in India. See FAO/STAT (March 16, 2017) available online: https://data.worldbank.org/indicator/ SN.ITK.DFCT; see also 2018 SOFI Report: http://www.fao.org/state-of-food-security-nutrition/ en/; for an understanding of the impact of natural disaster induced hunger and their economic consequences, see Gordon, K.P., The Chilean Protein Problem: A Case Study (Cornell University, 1975); see also ['Hunger Games'] supra n. 1. The children of women born just before the Great Leap Forward famine in China or the 1960 earthquake in Chile - that periods of severe undernourishment during childhood often damage the health of one's offspring born decades later.

${ }^{41}$ See Sen, A., Poverty and Famines: An Essay on Entitlement and Deprivation (Oxford University Press, 1983) at 257. As key contributor to the associated risks of non-communicable diseases, poverty creates greater social inequality due to inability to access adequate food and essential healthcare; see also Reutlinger, S and Selowsky, M., "Malnutrition and Poverty: Magnitude and Policy Options", World Bank Staff Occasional Paper No. 23 (1976) for underlying determinants of hunger.

${ }^{42}$ India Brand Equity Foundation, Highlights of the Union Budget 2018-2019, available online: https://www.ibef.org/economy/union-budget-2018-19. It is noteworthy that the budget 2017 targeted Rs 10 lakh crores ( US $\$ 157.2$ billion) for agricultural credit in 2017-2018.
} 
$24 \%$ higher than the previous year. ${ }^{43}$ The interlinked challenges of production, equity and resilience need thorough systemic reform so that the future will not be one of zero-sum competition between States, resource grabs by powerful elites and ecological collapse. In that light, building a sustainable bio-economy expects that disciplines of science, law and policy intertwine and help identify a nexus between food, health and climate justice especially to close prevailing inequalities between developing agrarian economies such as India, and other developed economies.

The following sections discuss regulatory aims, efforts and challenges posed to the Indian government followed by suggestions for a possible way forward.

\subsubsection{UNFAO CPF for India: New Aspirations for Zero Hunger}

The UNFAO Country Programming Framework (CPF) for India envisions a strong involvement from national stakeholders, both the private and the government sector. ${ }^{44}$ The main policy-making wing of the government, NITI Aayog's 7 year National Development Agenda, the medium-term 3 Year Action Agenda as well as the Union Budget contain overarching framework for the agriculture sector and enhancing farmers' income and wellbeing in the main. ${ }^{45}$ The aim is to double the farmers' income in a period of 5 years by effectuating efficient solutions and ensuring equity in a sustainable manner. ${ }^{46}$ Since the IFPRI Global Hunger Index in 2014, India has focused on community development as a means for capacity building. As per the 2015-2017 CPF, '[t]he areas that [will be]... prioritised are sustainable agricultural development, food and nutritional security, transboundary cooperation that includes India's contribution to global public goods... and climate change as cross-cutting issues wherever they are applicable'.

In order to combat climate change, the goal for UNFAO and India is to increase the community capacities to adapt farming patterns by applying strategies that will help minimize the effects of climate change in India. ${ }^{47}$ Furthermore, newer schemes for knowledge sharing through digital networks (e-Krishi Samvad) have been introduced in May 2017,48 similar projects for improved access to irrigation

\footnotetext{
${ }^{43}$ The Indian agriculture sector includes - agriculture (Agriculture proper \& Livestock), forestry and logging, fishing and related activities. The Indian agriculture and allied sector contributes $17.32 \%$ of the gross value added (GVA), which was around Rs 23.82 lakh crore INR in 20162017. See The Central Statistics Office, India (updated as on November 2017). See also source: Ministry of Statistics and Programme Implementation, Planning Commission of the government of India, http://statisticstimes.com/economy/sectorwise-gdp-contribution-of-india.php

${ }^{44}$ See UNFAO India CPF, 2018 available online: http://www.fao.org/india/programmes-and-projects/en/

${ }^{45}$ Ibid.

${ }^{46}$ See Agenda 2017-2018 - "Transform, Energise and Clean India” https://www.indiabudget.gov. in/budget2017-2018/ub2017-18/bh/bh1.pdf

${ }^{47}$ UN FAO India CFP, 2015-17

${ }^{48}$ It is noteworthy to mention the 'Digital India' initiative (http://www.digitalindia.gov.in/) which aims to make India a digitally empowered society and knowledge economy; for understanding of Smart regulation, Gunningham, N and Sinclair, D., "Smart Regulation" in Drahos, P ed., Regulatory
} 
(Pradhanmantri Gram Sinchai Yojna (PGSY)) implemented, and farmers motivated to adopt sustainable and organic farming (Paramparagat Krishi Vikas Yojna (PKVY)). Moreover, to improve sales of the agricultural produce and allow for network benefits among farmers, all Agriculture Produce Marketing Committees were unified to create an Electronic National Agricultural Market (eNAM) in April 2016.

\section{Agroecological Practices Versus IP-Centred Industrial Model}

Increased drought, soil salinity, pests and disease, adaptation to climate change in many agricultural regions may require stress-tolerant plant varieties. Thus genetic engineering and plant breeding as an approach for increasing the availability and adequacy of global food supplies has become prevalent. IP privileges can help attract investment in R\&D of new plant varieties (PV) that would enable adaptation. Recognizing a market opportunity, companies have begun marketing GM plants that are tolerant to a variety of stress factors such as abscisic acid, which is a hormone that regulates plant growth, discovered in 2009 under the Bayer Climate Program. ${ }^{49}$

While IP is often considered necessary for innovation, it is my view that it is never sufficient by itself to catalyse it. A competitive environment is quite necessary as well. Otherwise, over time any monopolist would have fewer incentives to innovate further ${ }^{50}$ and may abuse the IP privilege. On that note, I look at the possible impact of adopting IP-centred agriculture instead of the sustainable alternative.

\footnotetext{
Theory, Foundations and Applications (Australian National University Press, 2017) at 133; see also Gunningham, N and Grabosky, P., Smart Regulation. Designing Environmental Policy (Oxford: Oxford University Press,) pp. 5-19.

${ }^{49}$ Bayer Climate Program, "Climate Protection and adaptation to climate change" available online, www.Climate.bayer.com/en/stress-tolerant-plants.aspx

${ }^{50}$ See Arrow, K (1962) "Economic welfare and the allocation of resources for invention" in Nelson, R. ed., The Rate and Direction of Inventive Activity, Princeton University Press, 1962, pp. 609-25. Also note that new theoretical models that have offered to test the Schumpeterian hypothesis (concentrated markets provide an innovative environment) in certain product markets while complimenting the Arrowian view have noted that the positive effects of market competition on innovative activity when competition is not intense is significant, whereas intense competition may reduce the reward for innovation thereby reducing the incentive to innovate. Therefore, a mere IP like exclusivity is insufficient. The relationship between product market competition, especially in laborintensive sectors such as agriculture, and the price-cost margin measurement (e.g. by means of Lerner's index) will not be stable. This is characteristic of agriculture markets in countries such as India and China. For reference, see especially, Aghion, P., Burgess, R., Redding, S and Zilibotti, F (2003), "The Unequal Effects of Liberalization: Theory and

Evidence from India" available online: http://econ.lse.ac.uk/staff/rburgess/wp/abrz031002.pdf.
} 


\subsection{Impact of Adopting Proprietary Plants and Seeds: An Overview}

\begin{tabular}{l|l}
\hline Instant or current impact & Long-term impact \\
\hline $\begin{array}{l}\text { Supra-competitive returns for many } \\
\text { years along with yield improvements }\end{array}$ & $\begin{array}{l}\text { At the expense of biological diversity as herbicides and } \\
\text { pesticides are sprayed over genetically altered crops }\end{array}$ \\
\hline $\begin{array}{l}\text { Short-term bump in yield, pressures } \\
\text { other farmers to adopt it as well as } \\
\text { to compete in the short term }\end{array}$ & Dependent on fertilisers and are water-intensive \\
$\begin{array}{l}\text { Slow the adoption of approved but } \\
\text { environmentally (unsound) } \\
\text { technologies, e.g. technologies such } \\
\text { as GM seeds, synthetic fertilisers } \\
\text { and pesticides and purchase of } \\
\text { economically costly staples }\end{array}$ & $\begin{array}{l}\text { Erosion of indigenous knowledge - such as manuring } \\
\text { and compost for soil replenishment }\end{array}$ \\
\hline Rapid price escalation & Excessive pricing has been observed and fined \\
\hline
\end{tabular}

Dependency on high-tech seeds by farmers in India, due to the instant gains, has been historically evidenced. ${ }^{51}$ They have in turn added to the regulatory woes while governing food security in India.

\subsubsection{Capitalism and Competition Concerns}

There exists high degree of concentration in the agriculture sector on a global scale. China National Chemical Corporation acquiring Syngenta, ${ }^{52}$ and more recently Bayer, the world's second largest agro-chemicals concern, taking over Monsanto, which is the world's largest Seed and Genomics Company exemplify it. ${ }^{53}$ Reportedly,

\footnotetext{
${ }^{51}$ See Ministry of Agriculture, "Cultivation of Genetically Modified Food Crops: Prospects and Effects" New Delhi, Loksabha Secretariat, 2012 ['The Acharya Report']; see also Tripathy, S and Rosencrantz, A., "Climate impacts food security and health" (March 25, 2018) The Statesman supra n.13 - [1]ow-cost or subsidized chemical-intensive farming has led to the depletion of traditional manuring practices that are a sustainable alternative. For a long-term solution to the problem, incentivizing traditional agricultural practices with resource management through a decentralized participatory approach needs to be adopted. Self-government authorities, namely, the Village Panchayats and the Gram Sabhas, can help with data collection at the grassroots level so as to comprehend the risks and uncertainties in their completeness. Otherwise, such glaring evidence gaps can lead to incorrect health narratives and polarize public debate on what should constitute as sustainable food system, without offering alternative workable solutions best suited for the Indian population.

${ }^{52}$ See Media Release on the ChemChina Syngenta acquisition, "Syngenta shareholders accept ChemChina Offer" (May 05, 2017) available online https://www.syngenta.com/media/mediareleases/yr-2017/05-05-2017; see also Press release on the DowChemicals and DuPont 'Merger of Equals,' "DowDupont Merger Successfully Completed" (Sept 01, 2017) available online https:// www.dow.com/en-us/news/press-releases/dowdupont-merger-successfully-completed

${ }^{53}$ See News Release on the Bayer Monsanto Acquisition, "Bayer Closes Monsanto Acquisition" (June 07, 2018) available online https://monsanto.com/news-releases/ bayer-closes-monsanto-acquisition/
} 
DuPont, Limagrain, Monsanto and Syngenta control over 50\% of global seed sales, and three firms, Archer Daniels Midland, Bunge and Cargill, control 90\% of global grain trade. ${ }^{54}$ Incidences of anticompetitive behaviour and wilfully subverting operation of free markets have been proven to cause inflated prices to purchasers or depressed prices to suppliers in several markets. ${ }^{55}$ These instances have severe negative effects on food security.

Increasing number of farmer suicides and poor seed sector governance are interlinked in India. ${ }^{56}$ The average farmer grapples with concerns related to income as well as basic livelihood, and these factors are magnified with further concentration through mergers and acquisitions. The fear that the acquisitions would further limit the number of sellers of seeds, chemicals, machinery and equipment from whom they have to buy, and also limit the number of customers for crops and livestock to whom they can sell, is pervasive. Thus, much depends on the government action through responsive regulation that will alleviate these fears by reforming systems that play the crucial role in reinvigorating the whole demand-supply affecting the agricultural produce in India.

\subsubsection{Seed Regulation and GMOs in India}

Crops involving the introgression of certain genes of Bacillus thuringiensis (naturally occurring bacteria) commonly referred to as $\mathrm{Bt}$ technology altered crops have been particularly controversial in India. Let us take the example of Monsanto, which was able to enter the Indian seed market due to the 1988 Seed Policy imposed by the World Bank, ${ }^{57}$ requiring the government to deregulate the seed sector in favour of private players. This

\footnotetext{
${ }^{54}$ Bailey, R., Oxfam International Report on "Growing a Better Future: Food justice in a resourceconstrained world" (May 31, 2011) at 6; see also "Global Seeds Business Market 2015-2022: Monsanto, DuPont, and Syngenta Leading Seed Companies Worldwide" (June 26, 2018) available online: https://www.prnewswire.com/news-releases/global-seeds-business-market2015-2022-monsanto-dupont-and-syngenta-leading-seed-companies-worldwide-300672455. html; for detailed analysis with seed company profiles, see Research and Markets, "Seeds - Global Strategic Business Report" (April 2018) available online: https://www.researchandmarkets.com/ research/8zmc4z/global_seeds?w=5

${ }^{55}$ The practices include abuse of patented seed technologies, price-fixing, the allocation of customers, etc. that have resulted in antitrust scrutiny and even fines and criminal charges in the USA. For detailed reference on the US episodes, see, Tuncak, B, "The 'new normal': Food, Climate Change and Intellectual Property" in Brown, A ed., Environmental Technologies, Intellectual Property and Climate Change (Edward Elgar, 2013) at 233.

${ }^{56}$ See generally, Tripathy, S and Rosencrantz, A., "Climate impacts food security and health" (March 25, 2018) The Statesman supra n. 15 - farmer suicides in India have been frequently associated with cotton farming, a non-food agricultural commodity that has been severely affected due to the pricing strategies and market practices of corporate conglomerate Monsanto. Monsanto's required annual repurchase of its "super-seeds" forces the farmer-purchasers of these seeds to incur unsustainable debt, leading to thousands of farmer suicides over the years; see also Gruère G and Sengupta D, "Bt Cotton and Farmer suicides in India: an evidence-based assessment" J Dev Stud. 2011; 47(2):316-37; see also Merriott D. "Factors associated with the Farmer suicide crisis in India” J Epidemiol Glob Health. 2016 Dec; 6(4):217-227. Epub 2016 Apr 11.

${ }^{57}$ New Policy on Seed Development, 1988 (September 16, 1988) available online: https://seednet. gov.in/PDFFILES/NEW_POLICY_NPSD.pdf
} 
seed policy resulted in Indian companies being locked into joint ventures with Monsanto. Eventually, the 'common heritage principle - promotion of free exchange of seeds amongst farmers' was replaced with the corporate's dominance as the IP right holder, and open pollinated seeds came to be replaced by hybrids in the market. ${ }^{58}$ Cotton now had to be cultivated as a monoculture, and this increased vulnerability to pests, disease and drought and crop failure. ${ }^{59}$ A stark increase in pesticide use on farms was noted. ${ }^{60}$ Eventually the bollworm became Bt resistant. ${ }^{61}$ However, Monsanto continued to push public resources to make the genetically modified seeds through public-private partnerships. ${ }^{62}$

The world's largest cotton producer and second-biggest cotton exporter, next only to China, ${ }^{63}$ the India case study on food regulations requires an understanding of the Bt cotton controversy, typically as a top-down approach with grave consequences. The field trials for Bt cotton were not done in accordance to the legal procedure and were in violation of the Environment Protection Act at the time. The unauthorized large-scale, multicentric, open-field trials of Bt cotton in 40 locations spread across 9 States in India, ${ }^{64}$ while initializing crops to GM technology has been

\footnotetext{
${ }^{58}$ For reference on protection for new varieties and hybrids, see Ramanna, A and Smale, M., "Rights and access to plant genetic resources under India's New Law" Dev Pol Rev. 2004; 22(4) 423-42; See Peschard, K., "Farmers' Rights and Food Sovereignty: Critical Insights from India" J. Peasant Stud 2014: 1085-1108.

${ }^{59}$ Ho, MW., "Farmer suicides and Bt cotton nightmare unfolding in India," Science in Society, 2010 http://www.i-sis.org.uk/farmersSuicidesBtCottonIndia.php

${ }^{60}$ Shiva, V., "Introduction" in Shiva V, Barker, D and Lockhart, C eds., The GMO Emperor Has No Clothes: A Global Citizen's Report on the State of GMOs (New Delhi: Navdanya, 2010), 11 to 26. See also Thomas, G and Tavernier, J-D., "Farmer-suicide in India: debating the role of biotechnology" Life Sci Soc Policy, 13:8, 2017. The practice of monoculture, increased chemical fertilization, rising resistance of bollworms, new pests and the destruction of predator species that control pests were responsible for pest-proneness in Bt cotton. As a result a 13-fold hike in pesticide use in comparison to the pre-Bt cotton era.

${ }^{61}$ See Cummins, J., “No Bt Resistance?” Science in Society 20, 34-35, 2003; see Kalaspurkar, R., "Deadly gift from Monsanto to India" Science in Society38, 51, 2008; see also Ho, MW., "Mealy Bug Plagues Bt Cotton fields in India and Pakistan” Science in Society 45, 2010.

${ }^{62}$ Shiva, V., "Monsanto in India- A Story of Corruption, Biopiracy, Seed Monopoly and Farmers' Suicides" in Shiva V, Barker, D and Lockhart, C eds., The GMO Emperor Has No Clothes: A Global Citizen's Report on the State of GMOs (New Delhi: Navdanya, 2010), 143-185.

${ }^{63}$ See Times of India "Cotton exports likely to jump 43\% in 2018-2019" (June 14, 2018) available online: https://timesofindia.indiatimes.com/business/india-business/cotton-exports-likely-tojump-43-in-2018-19/articleshow/64586372.cms. India's cotton exports are expected to jump 43\% to 10 million bales (of 170 kilograms each) in the 2018-2019 marketing year on strong overseas demand, especially from China, according to industry body Cotton Association of India (CAI).

${ }^{64}$ The Biosafety Framework of India calls for prior authorization from the Genetic Engineering Appraisal Committee (GEAC) of the Department of Environment Forests and Wildlife (now Ministry of Environment Forests and Climate Change), for conducting any trials related to GMO in India. See Article 4 of the Biosafety Rules for the Manufacture, Use, Import, Export and Storage of Hazardous Micro Organisms, Genetically Engineered Organisms or Cells (notified under the Environmental Protection Act, 1986) available online: http://www.geacindia.gov.in/acts-and-rules. aspx; for information on GEAC, see specifically, the Institutional Biosafety Committee u/Article 4 (3) (1) on Competent Authorities, http://www.geacindia.gov.in/resource-documents/biosafetyregulations/acts-and-rules/Rules-for-the-manufacture-use-import-export-and-storage-1989.pdf
} 
criticized as regulatory failure. ${ }^{65}$ The contamination due to the trials is said to have severely compromised food safety by negatively impacting the entire food chain and overall health of consumers in India. ${ }^{66}$

Monsanto violated the Rules for the Manufacture, Use, Import, Export and Storage of Hazardous Micro-organisms, Genetically Engineered Organisms or Cells, 1989 (notified under the Environment Protection Act, 1986), ${ }^{67}$ by failing to seek approvals from the authorized government body, namely, the Genetic Engineering Appraisal Committee (GEAC) prior to importing over 100 grams of cottonseeds containing the MON531-Bt gene into India through its Indian subsidiary company, Mahyco, in 1995 for conducting the large-scale open-field trials. ${ }^{68}$

\footnotetext{
${ }^{65}$ See Ramaswamy, B et al., "The spread of illegal transgenic cotton varieties in India: Biosafety regulation, monopoly and enforcement" World Dev. 2012, 40(1):177-88; See opposing view, Herring, R., "Why did 'operation cremate Monsanto' fail? Science and class in India's great terminator-technology hoax" Crit Asian Stud 2006; 38(4): 467-93; see Herring, R., "State Science, Risk and Agricultural Biotechnology: Bt Cotton to Bt Brinjal in India" J Peasant Stud 2015, 42(1) 159-86 (Monsanto gained from an advantaged market position thanks to India's bio-safety regulations and not due to monopoly in seed sector.)
}

${ }^{66}$ Shiva, V., "The Seeds of Suicide: How Monsanto destroys Farming" available online http://www. globalresearch.ca/the-seeds-of-suicide-how-monsanto-destroys-farming/5329947; some discussion on the successful adoption of technology also exists. For instance, Keith Kloor views differently from Vandana Shiva; "Bt cotton has been all the rage in India since it was officially approved in 2002. The technology has been adopted by over $90 \%$ of Indian cotton farmers. Multiple studies point to significant reduction in pesticide spraying and subsequent cost savings for cotton farmers. India has harvested an average of 5.1 million tons of cotton per year, which is well above the highest production of 3 million tons before the introduction of Bt cotton". See Kloor, K., "The GMOSuicide Myth." Issues in Science and Technology 30, no. 2 (Winter 2014). Note that similar findings attest to the same in China, where Bt cotton accounts for $80 \%$ of its crop. See for example, Lang, S., "Seven year glitch: Cornell warns that Chinese Bt Cotton farmers are losing money due to 'secondary' pests" ChronicleOnline Cornell University (25 July 2006) http://news.cornell.edu/ stories/2006/07/bt-cotton-china-fails-reap-profit-after-seven-years See especially, Ho, MW., "Farmer suicides and Bt cotton nightmare unfolding in India," Science in Society, 2010 http:// www.i-sis.org.uk/farmersSuicidesBtCottonIndia.php (China was initially held up as the success story on Bt cotton [...]. It first granted permission to Monsanto to grow the crop in 1997, and for the first several years reported great reductions in the use of pesticides. Early warnings appeared in a study published in 2002 by researchers at an institute funded by China's Environmental Protection Agency. It found that although Bt cotton was effective in controlling bollworm, it had adverse impacts on the bollworm's natural enemies and was not effective in controlling many secondary pests. A second study published in October 2004 found that Bt cotton did not reduce the total numbers of insecticide sprays because additional sprays were needed against sucking pests. A study of 481 Chinese farmers by researchers at the Cornell University released in 2006 reported that after 7 years, populations of other insects such as mirids have increased so much that farmers have had to spray their crops up to 20 times a growing season). For similar discussion in regards to Indonesia and United States as well, see Gala, RM., "GM Cotton Fiascos around the world" Science in Society 26-27 (2005).

${ }^{67}$ See Article 7 on Approvals and Prohibitions in the Biosafety Rules, http://www.geacindia.gov.in/ resource-documents/biosafety-regulations/acts-and-rules/Rules-for-the-manufacture-use-importexport-and-storage-1989.pdf

${ }^{68}$ Mahyco, a Monsanto joint-venture had obtained permission for small controlled trials from the Review Committee of Genetic Manipulation (RCGM) under the Department of Biotechnology. The RCGM is a body that monitors the safety of on-going research projects and activities involv- 
These field trials were conducted without following the evaluation protocol and exposed the environment to biosafety risks and genetic pollution. Further no postharvest management of transgenic plants or disposal precautions as required by the Biosafety Guidelines, 1994, was observed. ${ }^{69}$ The infected fields were replanted with food crops in less than a year, and the food chain was irreversibly plagued by GMOs that were unverified and potentially unsafe for both health and environment. The integrity of the genetic engineering regulatory procedures was questioned by a public interest litigation (PIL) filed before the Supreme Court of India in 1999. ${ }^{70}$ This led to a temporary ban on the field trials until the GEAC could satisfactorily confirm that the safety to human health and environment was guaranteed.

Meanwhile, former US President Bill Clinton's India visit in March 2000 culminated on a high note, when despite the pending PIL Monsanto's Bt cotton was handed the necessary biosafety approval by the Department of Biotechnology (DBT). Furthermore the procedural rules were amended such that the RCGM under DBT was now empowered to approve multilocational small-scale field trials for a total of 20 acres up to 1 acre each. ${ }^{71}$ A classic case of regulatory capitalism in action, ${ }^{72}$ Monsanto's transgenic seeds found their way into the Indian farms despite several pending trials at the time and eventually replaced indigenous cultivars with hybrids as a result of self-pollination. ${ }^{73}$ Easy provisions of micro-credits from local banks and at times distribution of free samples for initial plantation were incentives designed to establish Monsanto's seed sales in India. Thus farmers became GM seed-dependent and incurred debt to overcome increasing input costs of seed purchase, water and pesticides. Low yield or at times no returns resulted in severe life

ing GMOs by prescribing guidelines specifying the regulatory procedure while conducting highrisk and controlled field experiments (lab research) with them. Its mandate is to review the compliance of such guidelines from a safety standpoint. It is not the authorized body for approvals for large-scale experiments and importation concerning GMOs. For information on RCGM, see specifically, Article 4 (2) on Competent Authorities ["Biosafety Rules"]

${ }^{69}$ Shiva, V., "Seed Satyagrah: A Movement for Farmers' Rights and Freedoms in a World of Intellectual Property Rights, Globalized Agriculture and Biotechnology" in Tokar, B., Redesigning Life?: The Worldwide challenge to Genetic Engineering (McGill-Queen's University Press, Montreal, 2001) at 355.

${ }^{70}$ Research Foundation for Science and Technology v. Union of India, filed on January 06, 1999; See especially, Kumar, S et al., "The legal battle over field trials of GM crops" Nature (January 31, 2014) available online: https://www.natureasia.com/en/nindia/article/10.1038/nindia.2014.14

${ }^{71}$ Damodaran, A., "Re-engineering biosafety regulations in India: Towards a critique of policy, law and prescriptions" Law Environ Dev Journal, 2005 1(1):1-20.

${ }^{72}$ Regulatory Capitalism refers to a trend that demonstrates how the pursuit of capitalistic growth often gives rise to more regulation and bureaucracy. See Levi-Faur, D, "The Global Diffusion of Regulatory Capitalism," Annals of the American Academy of Political and Social Science, 598:1232 (2005).

${ }^{73}$ See Shiva, V., "25 Years of Bija Swaraj" in Shiva V et al eds, Seed Freedom: A Global Citizen Report by Navdanya (New Delhi: Navdanya, 2012), 57-85; see also Scoones, I., Contentious Politics, Contentious Knowledges: Mobilising Against GM Crops in India, South Africa and Brazil (Sussex: Institute of Development Studies, 2005). Bija Panchayat or Seed Tribunals were especially set up in 2000 in Indian villages for conducting hearings against Monsanto before jury comprising of village heads and farmers. 
stresses for farmers in several regions of agrarian India. Overtime the Bt cotton production significantly declined causing an uproar of identity politics and public outcry.

\subsubsection{Litigation Concerning Ag-Biotech (Gene) Patents in India}

Monsanto was granted patent on second-generation Bt gene technology (licensed under the trademark Bollgard II variety), which increases resistance of the cotton seeds against the bollworm, a pest of the lepidopteran species on March 20, 2009. ${ }^{74}$ Mahyco Monsanto Biotech (India) Ltd., a joint venture company, issued sublicenses to Indian breeders and seed companies to develop varieties introgressed with Bt gene technology. ${ }^{75}$ The breeders would pay a technology licensing fee to Monsanto and sell the genetically modified seed varieties to farmers, who were charged retail prices. Without any patent on the first generation of the Bt gene technology, Monsanto had to lower the technology licensing fee for the breeders to enjoy benefits of market entry. However, Monsanto was found to be charging excessively for its patented version of the technology later. ${ }^{76}$ With the retail price of the seeds escalating, the State governments passed price control legislation to ensure seed affordability. ${ }^{77}$ To sidestep these regulatory hurdles, Monsanto proceeded with filing a patent for the second-generation Bt gene technology and was granted exclusive rights to commercialize and price it for specified period of 20 years. The breeders were now paying higher royalty accounting for the 'trait value' and 'technology license fees', and subsequently profits from sale of seeds were unstable due to the State law. Thus conflicts arose. Non-payment of royalty by the eight Indian seed companies (or breeders) led to the termination of their license agreements. Series of arbitration proceedings ${ }^{78}$ and patent infringement suits ${ }^{79}$ were also instituted by Monsanto. The Indian seed companies led by Nuziveedu Seeds Limited have countered the court action by questioning the validity of Monsanto's patent and the legal basis for charging royalty rates that are higher than the government fixed rate under the Cotton Seeds Price Control

\footnotetext{
${ }^{74}$ See Indian patent 232681 claim description available online: http://www.allindianpatents.com/ patents/232681-cotton-event-mon15985-and-compositions-and-methods-for-detection. It draws priority from US 60/297, 406 for the 'Cotton event Mon 15985 and compositions and methods for detection.

${ }^{75}$ For understanding of the Plant Varieties Protection Regime in India, and the infringement action under the Act, see Chap. 16 of this book by Lakshmikumaran, M.

${ }^{76}$ See Overwalle, G and Dycke, L., "Genetically Modified Crops and Intellectual Property Laws: Interpreting Indian Patents on Bt Cotton in View of the Socio-Political Background, 8 (2017) JIPITEC 151.

${ }^{77}$ For instance, see The Andhra Pradesh Cotton Seeds (Regulation of Supply, Distribution, Sale and Fixation of Sale Price) Act, 2007 (Act No. 29 of 2007).

${ }^{78}$ See Monsanto's arbitration proceedings before Bombay HC discussed generally by Reddy, P., "Delhi High Court Declines to Grant Monsanto an Interim Injunction in Dispute with Nuziveedu" SpicyIP (March 29, 2017) available online: https://spicyip.com/2017/03/delhi-high-court-rulesdeclines-to-grant-monsanto-an-interim-injunction-in-dispute-with-nuziveedu.html

${ }^{79}$ Monsanto v Nuziveedu Seeds Ltd. (Delhi HC) decided on March 28, 2017 by Single Judge R. K Gauba. Order available online: http://lobis.nic.in/ddir/dhc/RKG/judgement/28-03-2017/ RKG28032017IA24062016.pdf
} 
Order (CSPCO), 2015. ${ }^{80}$ The single judge of the Delhi High Court held the patent to be prima facie valid but directed that the royalty rate be aligned to the $\mathrm{CSPCO}^{81}$ rate. An appeal was preferred, and the Division bench of the High Court summarily held that Monsanto's invention was ineligible under Section 3(j) of the Indian Patent Act, 1970. The provision, that excludes plants from patent eligibility in India. ${ }^{82}$ This decision was appealed before the Apex Court.

Meanwhile, several attempts at fixing the licensing fee through specialized price control orders for regulating the cotton seed industry nationally has been made. These include: appeal for standardization, ${ }^{83}$ and seeking enhancement in the supply of the patented technology through applications for compulsory licensing. ${ }^{84}$

On May 18, 2016 a new set of licensing and formats for GM technology agreements guidelines were issued with a fixed rate of royalty. ${ }^{85}$ These guidelines required Monsanto's Bollgard II to be considered as a 'standard essential patent,' thereby stating among other things that 'all patentees of GM technology [are] to offer technology on fair, reasonable and non-discriminatory (FRAND) basis to any seed company willing to pay Monsanto, a government mandated royalty'. Drafted under clause $5(8)$ of the $\mathrm{CSPCO},{ }^{86}$ these guidelines were later withdrawn as they were held to be ultra vires the scope of the Essential Commodities Act, 1955.

\footnotetext{
${ }^{80} \mathrm{Ibid}$, at paras 17 and 18 discussing the defendants written statements

${ }^{81}$ Gazette Notification No. G.S.R.936 (E) dated December 7, 2015, under Section 3 of the Essential Commodities Act, 1955. Legislation used to control the royalty or licensing fee for the use of a patent or for technology transfer. The legislation vests in the government, powers to control the prices of a wide range of essential commodities such as drugs, food crops, sugar, foodstuffs, etc. for the purpose of securing the "equitable distribution and availability of these commodities at fair prices or for maintaining or increasing supplies of the same." For the text of the Legislation, see: https://consumeraffairs.nic.in/consumer/sites/default/files/userfiles/ecact1955.pdf

${ }^{82}$ Monsanto v Nuziveedu Seeds Ltd. (Delhi HC, Division Bench) decided on March 09, 2018 by the Division Bench of Justices Rohinton Nariman and Navin Sinha. See also DB Order dated May 08, 2017, available online: http://delhihighcourt.nic.in/dhcqrydisp_o.asp?pn=98458\&yr=2017

${ }^{83}$ See generally, Fernandes, V., "Why is Prabhakar Rao of Nuziveedu Seeds fond of FRAND licensing?" (Dec 17, 2015) available online: http://www.smartindianagriculture.in/why-is-prabhakar-rao-of-nuziveedu-seeds-fond-of-frand-licensing/to be read with Vacca, R, Cole, BM and Brent, BJ., "Food for Thought: Genetically Modified Seeds as De Facto Standard Essential Patents" (March 12, 2014) 85 University of Colorado Law Rev. 313 (2014); U of Akron Legal Studies Research Paper No 13-7, available online: https://papers.ssrn.com/sol3/papers. cfm?abstract_id $=2245887$ for assertion related to GM Seeds as standard essential patents; For understanding of Standard Essential Patents and FRAND Licensing generally, see Chap. 5 of this conference volume by Dhar, B on India's technology industry.

${ }^{84}$ For understanding of compulsory licensing as a part of the patent policy generally, see Chap. 12 of this volume by Racherla, U.S., "The Historical Evolution in Patenting in the Indian Pharmaceutical Industry and Its Impact on Innovation."

${ }^{85}$ Ministry of Agriculture Notification u/clause 5(8) of CSPCO (May 18, 2016) "Licensing and Formats for GM technology Agreements Guidelines, 2016" [The 2016 Guidelines]

${ }^{86}$ The 'CSPCO' derives its authority from the Essential Commodities Act, 1955. Legislation used to control the royalty or licensing fee for the use of a patent or for technology transfer. The legislation vests in the government, powers to control the prices of a wide range of essential commodities such as drugs, food crops, sugar, foodstuffs, etc. for the purpose of securing the "equitable distribu-
} 
To add to the fiasco, State government of Andhra Pradesh and the Department of Industrial Policy and Promotion (DIPP), which functions under the Ministry of Commerce and Industry, sought for outright revocation of Monsanto's patent, on the grounds of it being mischievous and prejudicial to public interest (Section 66 of the Indian Patent Act, 1970). ${ }^{87}$ Furthermore, the State government of Andhra Pradesh urged that the central government invoke powers under Section 92 of the Patent Act and issue a compulsory license for making Monsanto's seed available at reasonable prices, as it was charging excessive royalties. The declaration of a compulsory license under Section 92 is made only in cases of national emergency or in case of extreme urgency or public noncommercial use. Therefore, such a compulsory license would not only interfere with the freedom to contract norms but also strengthen the provision as an enforcement mechanism or competition remedy within the patent regime.

Finally, based on the reference received from the Ministry of Agriculture and a complaint by the Indian seed company (Nuziveedu Ltd), Monsanto's licensing practices were subject to competition scrutiny in India. ${ }^{88} \mathrm{~A}$ prima facie case of abuse of dominant position and restrictive licensing practices has been established as well. ${ }^{89}$

More recently, on January 8, 2019 the Apex Court decided the aforementioned commercial dispute between Monsanto and Nuziveedu Seeds Ltd. ${ }^{90}$ The question of

tion and availability of these commodities at fair prices or for maintaining or increasing supplies of the same." For the text of the Legislation, see: https://consumeraffairs.nic.in/consumer/sites/ default/files/userfiles/ecact1955.pdf

${ }^{87}$ Section 66 of the Patent Act, 1970: Revocation of patent in public interest - Where the Central Government is of opinion that a patent or the mode in which it is exercised is mischievous to the State or generally prejudicial to the public, it may, after giving the patentee an opportunity to be heard, make a declaration to that effect in the Official Gazette and thereupon the patent shall be deemed to be revoked. For a historical account of the two episodes of patent revocations u/S 66, see the case of Agracerus's process patent on 'the method of producing transformed cotton cell lines by tissue culture' (Indian patent number 168950) which was revoked in the year 1994, for being prejudicial to the interests of Indian farmers as it had 'far-reaching implications for India's cotton economy'. See also the case of Avasthagen's patent on 'synergistic ayurvedic/functional food bioactive composition' (Indian patent 1076/CHE/2007) used as a medicine to treat diabetes, which was revoked in the year 2012 on the finding that it was based on the traditional medicinal knowledge held by indigenous communities in India.

${ }^{88}$ See specifically, CCI Reference Case No. 2 of 2015 and Case No 0.107 of 2015: https://indiankanoon.org/doc/122804601/?type=print; based on Justice BN Srikrishna's recommendation, the National Seed Association of India (NSAI) has sought suitable corrective action through the CCI; see Economic Times Report, "Hybrid seed producers want government to move CCI against Mahyco Monsanto" (October 15, 2015) available online: https://economictimes.indiatimes.com/ news/economy/agriculture/hybrid-seed-producers-want-government-to-move-cci-against-mahyco-monsanto/articleshow/49367624.cms; also see CCI Order dated July 26, 2016, available online: https://www.cci.gov.in/sites/default/files/Ref\%20Case $\% 20022015 \% 20 \% 26 \% 20$ others. pdf;

${ }^{89} \mathrm{CCI}$ 's prima facie order u/S 26 (1) against Monsanto (Order dated June 09, 2016): https://www. cci.gov.in/sites/default/files/Ref\%2002-2015\%20and\%20107-2015\%20-26(1)\%20 order_10.02.2015.pdf

${ }^{90}$ Supreme Court of India, Monsanto v Nuziveedu Seeds Ltd. decided on January 08, 2019, https:// www.sci.gov.in/supremecourt/2018/16059/16059_2018_Judgement_08-Jan-2019.pdf 
patent validity has been reverted back to the trial court for a full-fledged hearing, while the license arrangements with the Indian seed companies have been revived on the condition that royalty be paid as per the CSPCO rates. Thus Monsanto's patented seed can be used by the Indian companies to develop the plant varieties upon fulfilment of the royalty condition. ${ }^{91}$ Clarity on the legality of ag-biotech patents in India will be gained once the question of validity is settled in the near future. That will also allow deliberation on the necessary regulatory robustness needed to minimize risks associated with the working of such ag-biotechnology products and processes as well as their overall impact in the long run.

\subsubsection{Other Noteworthy Developments}

Another significant example in terms of regulating use of Bt technology for developing GM food in India is that of 'Bt Brinjal'. The gene modification claims to make the plant pest resistant. Indian farms were affected as a result of pollen drift from Bangladesh. The Ministry of Environment and Forest (MoEF) ordered for a moratorium in 2010 calling for a better understanding of the impact of such pollen drift safety studies to assess impact on environment as well as human health and for eco-labelling practices. ${ }^{92}$ Despite the safety concerns, the increase in price of the seeds in Bangladesh was noted to be almost three times more, and no seed saving was registered. ${ }^{93}$ With reduced price of pesticides, the GM seed sales were offset. The crop losses to pests were found to be fewer, while the crop yield from the Bt plant was disappointingly lower than expected.

Learning from the Bangladeshi experience, the government of India called for consultations on the Bt brinjal adoption. The mandate was to develop institutional structures and capacity to ensure safety to the environmental and human health, farmers' and

\footnotetext{
${ }^{91}$ Basheer, S., "The Monsanto Bt Cotton case is not over yet" Hindustan Times (January 10, 2019) available online: https://www.hindustantimes.com/analysis/the-monsanto-bt-cotton- case-is-notover-yet/story-weAMtHbuDSsCumrhpLzfIK.html?fbclid=IwAR0AJIfEtRdFIO750FX_cqRfpkIs LXxOVhRT_8VPofMF1oucyzM6avk4kL8

${ }^{92} \mathrm{Bt}$ Brinjal moratorium 2010; also note that Bt cotton has been more expensive than Bt Brinjal, but the yield still returned a net profit of Rs. 5,294 in 2003 as compared to Rs. 3,133 per acre for conventional cotton. See Brooke Glass-O'Shea (7 J. Food L. \& Pol'y 12011 ) - regional variations in yield returns are due to geographic conditions, droughts and over use of pesticides which increased the input costs - especially in the State of Andhra Pradesh. Average yield gains in states other than Andhra Pradesh were up to $42 \%$ to $59 \%$.

${ }^{93}$ See, Robinson, C., "Bt Brinjal on "life support" in Bangladesh" GMWatch (November 17, 2015): https://gmwatch.org/en/news/latest-news/16535; for counterview see Shelton AM, Hossain MJ, Paranjape V, Azad AK, Rahman ML, Khan ASMMR, Prodhan MZH, Rashid MA, Majumder R, Hossain MA, Hussain SS, Huesing JE and McCandless L (2018). Bt eggplant project in Bangladesh: History, present status, and future direction. Front. Bioeng. Biotechnol. 6:106. doi: https://doi. org/10.3389/fbioe.2018.00106; see also Antoniou MN, Robinson CJ (2017). Cornell Alliance for Science evaluation of consensus on genetically modified food safety: Weaknesses in study design. Front. Public Health. 13 April. https://www.frontiersin.org/articles/10.3389/fpubh.2017.00079/ full; see especially, GMWatch, "GM Bt Brinjal in Bangladesh: GMO win or smoke and mirrors?" (September 03, 2018) available online: https://gmwatch.org/en/news/ latest-news/18447-gm-bt-brinjal-in-bangladesh-gmo-win-or-smoke-and-mirrors
} 
consumers' rights and inclusive decision-making for GM crops. However, not a single attempt has been made in this direction since the consultation. ${ }^{94}$

However, GM mustard - Dhara Mustard Hybrid (DMH-11) ${ }^{95}$ which has been developed by scientists at Delhi University for a project that is part-funded by the Department of Biotechnology, a division of the Science Ministry - has come to be the first transgenic food crop to be allowed for commercial cultivation in India. The GEAC after conducting a safety study cleared it to be commercially cultivated for 4 years. However, independent safety study has been requested by citizen groups which have led to a stay on the introduction pending re-release and evaluation of the study. The Supreme Court is awaiting the status report from the centre ${ }^{96}$ on the matter. Thus, the issue of GMOs is likely to continue testing the workings of the existing regulatory framework in India.

\section{Conclusion}

With a paucity of studies that validate the impact of GM crops on human health, regulation in this area has been problematic for India. ${ }^{97}$ Moreover the current trend of stronger IP favours a regime where the industrial style of agriculture - one which promotes dependency on synthetic chemicals and monoculture production models thrives. Monocultures are ill-suited for traditional models of farming dependent on diverse crop varieties and traditional techniques. ${ }^{98}$ Apparently, from more than 100,000 varieties of rice during the 1970 s in India, only 6000 varieties are available today. ${ }^{99}$ Gene diversity requires a diversity of knowledge forms. The sector calls for

\footnotetext{
${ }^{94}$ See MoEF, Government of India, "National consultation on Bt Brinjal" available online: http:// www.moef.nic.in/downloads/public-information/Bt\%20Brinjal\%20Primer.pdf; see also Report of the Expert Committee (EC-II) on Bt Brinjal Event EE1.: (2009) Developed by: M/s Maharashtra Hybrid Seeds Company Ltd. (Mahyco), Mumbai, University of Agricultural Sciences (UAS), Dharwad and Tamil Nadu Agricultural University (TNAU), Coimbatore. Genetic Engineering Approval Committee, Ministry of Environment and Forests, Government of India, New Delhi, available online: http://www.moef.nic.in/downloads/publicinformation/Report $\% 20$ on\%20Bt\%20 brinjal.pdf

${ }^{95}$ This variety has two main functions that could be attributed to its GM traits. The first is it makes hybridization for mustard easier, since mustard is a self-pollinated plant, and it is not easy to produce hybrids for mustard. Second, it has a gene that provides the plant with herbicide tolerance.

${ }^{96}$ Press Trust of India, "Supreme Court seeks Center's reply on field trials of GM Mustard crops" NDTV (October 30, 2018) available online: https://www.ndtv.com/india-news/ supreme-court-seeks-centres-reply-on-field-trials-of-gm-mustard-crop-1940273

${ }^{97}$ For a comparative understanding of the European experience while regulating GMOs, Hartley, S and Millar, K.M., "The Challenges of Consulting the Public on Science Policy: Examining the development of European Risk Assessment Policy for Genetically Modified Animals" Review of Policy Research, 31:6, 2004 at 481.

${ }^{98}$ See Kochupillai, M, Promoting Sustainable Innovations in Plant Varieties (Springer 2016).

${ }^{99}$ Basheer, S "Pest Policy: Confusion, Capture or a Fetish for the Foreign?" (October 30, 2017) SpicyIP, https://spicyip.com/2017/10/pest-policy-confusion-capture-or-a-fetish-for-the-foreign. html
} 
a greater understanding of the relation between regulation and risk, since collective well-being is at stake.

With the Intergovernmental Panel on Climate Change (IPCC) Special Report 2018, informing that the planet is likely to die sooner than later, ${ }^{100}$ ignoring the cumulative risks of regulatory failure in addressing food insecurity, poor nutritional health and climate change is no more a black swan event but a definite certainty. ${ }^{101}$ Failure to acknowledge the nature and magnitude of harm is not an option anymore. In order to avoid terrible hindsight, the Indian bio-economy requires serious attention and proactive action from all quarters of government and citizenry.

It serves to question at this point, how far science at its self-reflective best can go to create a case for ecological science as 'the sustainable solution'? As the UN Committee on Economic Social and Cultural Rights in general comment 12 realization of a 'right to food' is everyone's responsibility - stated, the transfer of technology for adaptation that is informed by human rights would increase the overall effectiveness of international efforts for protecting human health and environment. ${ }^{102}$ Thus, a right-based approach to regulation, in this case, a right to food, requires full regulatory thrust to play an influential role in discussions over adaptation, as well as the innovation of and access to climate-related technologies and know how. The effectiveness of NFSA depends on successful implementation of such an approach.

Measures to involve key private sector partners to invest in sustainable agriculture will encourage financing mechanisms for developing climate resilience and access and benefit-sharing regimes. ${ }^{103}$ There is a pressing need to develop consensus on private sector investor advisory for adaptation funding so as to further sustainability goals.

Agricultural productivity has direct implications for poverty alleviation. Labourintensive farming in populous countries such as China and India can particularly benefit from increase in produce, as not only wages for farmers would improve as a result, but the cost of basic foods which make up a large share of the poor's expenditures is likely to plummet as well. ${ }^{104}$ Till such time, the claim made by the

${ }^{100}$ IPCC Special Report, 2018, see https://www.ipcc.ch/sr15/ Global temperatures could rise by $1.5^{\circ} \mathrm{C}$ by as early as the year 2030 and we ought to become carbon neutral urgently by 2050 .

${ }^{101} \mathrm{~A}$ black swan event is referred to as an occurrence that deviates beyond what is normally expected of a situation and is extremely difficult to predict. See especially, Taleb, N, The Black Swan: The Impact of the highly improbable (Penguin Books, 2007).

${ }^{102}$ UNHCHR, the general comment 12, contained in document E/C.12/1999/5.

${ }^{103}$ For an early discussion about developing sustainable food systems in India from an ecologists' perspective, see Ho, MW et al., (2008) "Food Futures Now" available online http://www.i-sis.org. uk/foodFutures.php

${ }^{104}$ See Ravallion, M and G. Datt 1996 “How Important to India's Poor Is the Sectoral Composition of Output?" World Bank Economic Review 10(1):1-25; see also Loayza, N and C. Raddatz 2010 "The Composition of Growth Matters for Poverty Alleviation" Journal of Development Economics 93:137-51; for a comparative discussion, see especially, Ivanic, M and W. Martin 2016 Sectoral Productivity Growth and Poverty Reduction: National and Global Impacts. Mimeo. International Food Policy Research Institute. 
UN agencies of having achieved the promised halving of the number of the hungry in the developing world in 2015 seems to be a fiction, at least in the Indian context.

Open Access This chapter is licensed under the terms of the Creative Commons Attribution 4.0 International License (http://creativecommons.org/licenses/by/4.0/), which permits use, sharing, adaptation, distribution and reproduction in any medium or format, as long as you give appropriate credit to the original author(s) and the source, provide a link to the Creative Commons license and indicate if changes were made.

The images or other third party material in this chapter are included in the chapter's Creative Commons license, unless indicated otherwise in a credit line to the material. If material is not included in the chapter's Creative Commons license and your intended use is not permitted by statutory regulation or exceeds the permitted use, you will need to obtain permission directly from the copyright holder.

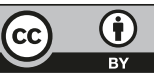

